\title{
PENINGKATAN AWARENESS, PENGETAHUAN DAN SIKAP DALAM KESELAMATAN BERKENDARA (SAFETY RIDING) UNTUK MURID SMKN 2 KOTA JAMBI
}

\author{
David Kusmawan \\ Program Studi Ilmu Kesehatan Masyarakat, Fakultas Kedokteran dan Ilmu Kesehatan, Universitas Jambi \\ kusmawandavid@gmail.com
}

\begin{abstract}
Motor vehicle accidents are multifactorial (human factors, vehicles and physical environment). The high percentage of young riders in motorbike accidents is a serious public health problem. There are at least three main reasons why underage (young) flaggers have a high risk of accidents. First the lack of age experience. The second is that young people are physically and emotionally immature, and thus less able to assess risk than older people. Third, the ease with which the license to drive itself is granted at a young age is also an important factor. The lower the minimum driving age, the higher the accident rate among novice drivers. Besides that the problem in our society is the lack of obedience to obey a rule. Non-compliance with this rule has contributed to the incidence rate of vehicle accidents on the highway which cause many losses, student behavior which includes driving safety, and the absence of public transportation facilities that pass through their schools. questions and answers about driving safety for students by sources from the campus and the police. From the measurement results through questionnaires through the pre-test and post-test mechanisms, it shows that for the knowledge variable there is an increase in the average value before the intervention from 7.85 to 9.48 after the intervention and statistically has a significance $P$-value of 0.005 . Meanwhile, for the attitude variable there was an increase in the average value before the intervention from 27.71 to 30.14 after the intervention and statistically it has a significance P-value of 0.005. Hopefully this training can be an initial contribution in creating a culture of driving safety among school students so that it will contribute to reducing the number of motor vehicle accidents. The intervention of various variables using the Haddon Matrix Framework approach has proven to be quite effective in relation to safety riding problems and the prevention of accidents and the resulting fatality.
\end{abstract}

Keywords; safety driving; smkn 2 jambi city; awareness; attitude and knowledge; kie

\begin{abstract}
Abstrak
Kecelakaan kendaraan bermotor bersifat multifaktor (faktor manusia, kendaraan dan lingkungan fisik). Persentase pengendara muda yang tinggi di dalam kecelakaan sepeda motor menjadi problem kesehatan masyarakat yang serius. Setidaknya terdapat tiga alasan utama mengapa pengendera di bawah umur (muda) mempunyai tingkat risiko kecelakaan yang tinggi. Pertama kurangnya pengalaman usia. Kedua adalah orang muda secara fisik dan emosional kurang dewasa, dan dengan demikian kurang dapat menilai risiko daripada yang lebih tua. Ketiga adalah mudahnya pemberian izin mengemudi sendiri pada usia yang muda juga merupakan faktor penting. Semakin rendah usia mengemudi minimum, semakin tinggi tingkat kecelakaan di antara driver pemula. Selain itu permasalahan di masyarakat kita adalah kurangnya kepatuhan untuk mentaati sebuah aturan. Ketidakpatuhan terhadap aturan ini telah berkontribusi terhadap tingkat kejadian kecelakaan kendaraan di jalan raya yang menimbulkan banyak kerugian, perilaku siswa yang meliputi keamanan berkendara, dan tidak adanya sarana transportasi umum yang melewati sekolah mereka. Metode pelaksanaan kegiatan pengabdian masyarakat dengan melakukan edukasi melalui kuliah, diskusi dan tanya jawab tentang keamanan berkendara bagi siswa oleh narasumber daripihak kampus dan pihak kepolisian. Dari hasil pengukuran melalui kuesioner melalui mekanisme pre-test dan post-test, menunjukkan hasil bahwa untuk variabel pengetahuan terjadi peningkatan nilai rata-rata sebelum intervensi 7.85 menjadi 9.48 setelah intervensi dan scara statistik memiliki kemaknaan P-value sebesar 0.005. Sementara untuk variabel sikap terjadi peningkatan nilai rata-rata sebleum intervensi 27.71 menjadi 30.14 setelah intervensi dan scara statistik memiliki kemaknaan $P$ - value 0.005 . Pelatihan ini semoga bisa menjadi kontribusi awal dalam penciptaan budaya keselamatan berkendara di kalangan siswa sekolah sehingga turut berkontribusi dalam pengurungan angka kecelakaan kendaraan bermotor. Intervensi berbagai macam variabel dengan pendekatan Haddon Matrix Framework terbukti cukup efektif terkait masalah safety riding dan pencegahan kecelakaan dan fatality yang ditimbulkan.
\end{abstract}

Kata Kunci: keselamatan berkendara; smkn 2 kota jambi; kesadaran; sikap dan perilaku; komunikasi informasi edukasi 


\section{Pendahuluan}

Cedera akibat sepeda motor merupakan penyebab utama kecacatan dan kematian di dunia dan terutama di negara berpenghasilan rendah dan menengah (Nyagwui et.al 2016) Jumlah kematian lalu lintas jalan tahunan mencapai 1,35 juta. Cedera lalu lintas jalan kini menjadi pembunuh utama orang berusia 5-29 tahun WHO (2018). Kecelakaan kendaraan bermotor bersifat multifaktor (faktor manusia, kendaraan dan lingkungan fisik). Faktor manusia seperti faktor kelelahan, alcohol, dan penggunanan obat, peningkatan jumlah kendaraan bermotor pada negara berkembang (Petridou et.al 2000, O'Neill et.al 2002). Persentase pengendara muda yang tinggi di dalam kecelakaan sepeda motor menjadi problem kesehatan masyarakat yang serius (Begg, Langley, Brookland, Ameratunga, \& Gulliver, 2014). Meskipun berakibat fatal dan berbiaya tinggi, hal ini bisa dicegah (CDC).

Sepeda motor dianggap sebagai salah satu moda transportasi ekstrem yang berkontribusi terhadap kecelakaan di jalan raya. Laporan mengungkapkan bahwa jumlah kematian yang disebabkan oleh sepeda motor jauh lebih tinggi dibandingkan dengan alat transportasi lainnya. Sebagian besar kecelakaan sepeda motor terjadi terutama karena perilaku manusia.

Jumlah kematian yang disebabkan oleh sepeda motor jauh lebih tinggi daripada moda transportasi lainnya, dan ini terutama karena kerentanan yang melekat dan paparan risiko pengendara sepeda motor (Anaya et. al 2017). Setidaknya terdapat tiga alasan utama mengapa pengendera di bawah umur (muda) mempunyai tingkat risiko kecelakaan yang tinggi. Pertama kurangnya pengalaman usia dan jenis kelamin. Pemberian izin mengemudi sendiri pada usia yang muda juga merupakan faktor penting. Semakin rendah usia mengemudi minimum, semakin tinggi tingkat kecelakaan di antara driver pemula. Orang muda secara fisik dan emosional kurang dewasa, dan dengan demikian kurang dapat menilai risiko daripada yang lebih tua (OECD 2006).

Salah satu permasalahan di masyarakat kita adalah kurangnya kepatuhan untuk mentaati sebuah aturan. Salah satu aturan yang sering dilanggar oleh masyarakat pengguna jalan adalah peraturan berkendara dan berlalu lintas. Ketidakpatuhan terhadap aturan ini sedikit banyak telah berkontribusi terhadap tingkat kejadian kecelakaan kendaraan di jalan raya yang menimbulkan banyak kerugian (material dan non material).

Berdasarkan data dari Penegakan Hukum (Gakkum) Korlantas Polri kejadian kecelakaan sepeda motor di Indonesia mengalami peningkatan sebesar 24\% dari tahun 2015 yang sebanyak (109.295 kasus) ke tahun 2016 sebanyak (135.883 kasus). Kejadian kecelakaan di kota Jambi cukup tinggi. Berdasarkan data Satuan Lalu Lintas (Satlantas) Polresta Kota Jambi, Kecelakaan lalu lintas yang terjadi di Provinsi Jambi pada tahun 2019 ini nengalami peningkatan 1.72 persen dibandingkan tahun sebelumnya. Pada tahun 2019, kecelakaan lalu intas yang terjadi sebanyak 1.180 kasus. Sedangkan pada tahun 2018 berada pada angka 1.160 kasus. Kondisi transportasi di Jambi antara lain banyaknya jumlah kendaran bermotor bermotor dan Sebagian besar jalan banyak berlobang sehingga berkontribusi terhadap kemacetan dan kecelakaan. Berdasarkan hasil observasi lapangan dan diskusi langsung dengan mitra yang telah dilakukan, setidaknya terdapat 3 aspek permasalahan yaitu:

Pertama adalah awareness orang tua dan guru yang meliputi izin mengendarai, safety riding, keamanan berkendara. Kedua adalah perilaku pelajar yang meliputi keamanan berkendara, psikologi dan tingkat pengetahuan (pengetahuan terkait obat, dan rambu lalu lintas, sikap dan perilaku). Ketiga adalah faktor pemicu penggunaan sepeda motor oleh pelajar yaitu tidak adanya sarana transportasi umum yang melewati sekolah mereka.

Oleh karena itu masyarakat umum yang akan menjadi mitra dalam program kemitraan masyarakat ini adalah SMKN 2 Kota Jambi.Berikut foto yang berhasil didapatkan di lapangan terkait kondisi perilaku dan keamanan pengendara motor (pelajar) di beberapa Sekolah Menengah: 
Adapun permasalahan mitra yang dapat di sampaikan disini adalah:

1. Masih rendahnya pengetahuan Siswa akan pentingnya keselamatan dalam berkendara.

2. Perilaku terhadap K3 masih rendah di sekolah.

3. Belum adanya program pengenalan $\mathrm{K} 3$ di sekolah.

Peningkatan awareness dan pengetahuan ini pada akhirnya bertujuan untuk membuat masyarakat mitra mengerti, mau, dan mampu untuk merubah perilaku dan sikap terkait kedisiplinan terhadap peraturan yang ada. Peran orang tua di dalam memberikan izin mengendarai turut memberikan kontribusi terhadap jumlah pengendara kendaraan bermotor di bawah umur. Berdasarkan hal tersebut diatas perlu dilakukan kegiatan pengabdian masyarakat

\section{Metode}

Dari hal tersebut diatas dilakukan kegiatan pengabdian masyarakat tentang "Usaha Peningkatan Awareness, Pengetahuan, dan Sikap Siswa SMKN 2 Kota Jambi dalam Keselamatan Berkendara (Safety Riding) dengan kegiatan kegiatan yang dilakukan adalah melalui pendekatan Komunikasi, Informasi dan Edukasi dan proses belajar. Berikut metode yang dipakai dalam melaksanakan program pengabdian kepada masyarakat:

1. Pemanasan

Metode ini berfungsi untuk bina suasana kelas yang hangat dan gembira untuk menarik perhatian peserta terhadap topik yang dibahasa

2. Ceramah tanya jawab

Suatu cara memberikan informasi kepada peserta yang berfungsi untuk menjelaskan sesuatu. Tanya jawab merupakan suatu cara untuk mengetahui apakah penjelalasan sudah jelas

3. Diskusi kelompok

Berfungsi sebagai arena saling bertukar informasi dan memcahkan maslah serta arena arena daya cipta dan daya anallisa

4. Drilling dan Penumbuhan Kesadaran

Berfungsi sebagai ekspresi spontanitas peserta dan penumbuh daya analisa serta membangkitkan kesadaran dari dalam diri untuk selalu berhati-hati.

5. Diskusi

Diskusi berfungsi sebagai arena saling pemantapan pengalaman saling tukar pengalaman dan analisa karya pribadi / kelompok serta terwujudnya kesimpulan bersama

6. $\quad$ Studi kasus

Berfungsi sebagai arena saling tukar informasi dan memecahkan maslah

7. Curah pendapat

Berfungsi membangkitkan keberanian peserta untuk mengungkapkan pendapat dan persaannya

a. Pembinaan dan tindak lanjut

1. Menyiapkan media dalan upaya menyebarluaskan informasi

2. Memberikan brosur, video, leaflet dalam mengedukasi siswa sekolah

b. Evaluasi

Keberhasilan suatu kegiatan dapat dinilai dari input proses dan output. untuk pelaksanaan kegiatan pengabdian masyarakat ini, menggunakan evaluasi yaitu evaluasi penyelanggraan dan evaluasi sumatif.

\section{Hasil dan Pembahasan}

SMKN 2 Kota Jambi terletak di Jl. Gelatik Pasir Putih Jambi, dengan Jumlah kelas sebanyak 50 dengan total pengajar dan staf sebanyak 98 orang dan total siswa sebanyak 1.037 orang. Fasilitas yang terdapat di SMKN 2 ini meliputi kelas, perpustakaan, laboratorium dan tata 
usaha, masjid, aula, lapangan upacara, lapangan olahraga, perpustakaan, tempat parkir kendaraan dan kantin. Kegiatan ekstrakurikuler meliputi PMR dan Paskibraka. Populasi pada kegiatan pengabdian masyarakat adalah siswa siswi SMKN 2 Kota Jambi. Adapun yang menjadi peserta responden dalam kegiatan ini adalah Siswa SMAN 2 Kota Jambi yang aktif atau pengurus pada organisasi siswa SMKN 2 Kota Jambi yang berjumlah 21 orang. Waktu kegiatan pengabdian masyarakat dilaksanakan mulai dari bulan Mei sampai dengan Desember 2020.

Pelaksanaan kegiatan pengabdian masyarakat "Usaha Peningkatan Awareness, Pengetahuan, Sikap dan Perilaku Siswa SMKN 2 Kota Jambi dalam Keselamatan Berkendara (Safety Riding) dapat dinilai dengan cara melakukan pre test dan post test sehingga diperoleh hasil pengukuran tingkat pengetahuan siswa sebelum mendapatkan pembelajaran tentang safety riding dalam berkendara sepeda motor dibandingkan dengan setelah mendapatkan pembelajaran. Adapun hasil analisis data kegiatan pengabdian masyarakat dapat dilihat pada tabel di bawah ini :

Tabel 1. Distribusi Frekuensi Berdasarkan Jenis Kelamin

\begin{tabular}{clccc}
\hline No. & Jenis Kelamin & Jumlah & $\%$ \\
\hline 1 & Laki-laki & 6 & 28.6 \\
\hline 2 & Perempuan & 15 & 71.4 \\
\hline & & Jumlah & 21 & 100 \\
\hline
\end{tabular}

Dari Tabel diatas menunjukan bahwa peserta kegiatan pengabdian masyarakat tentang "Peningkatan Awareness, Pengetahuan, Sikap Siswa SMKN 2 Kota Jambi dalam Keselamatan Berkendara (Safety Riding) : Intervensi Haddon Matrix Framework, sebesar $71.4 \%$ merupakan perempuan.

Tabel 2. Distribusi Frekuensi Bedasarkan Umur

\begin{tabular}{rlrrr}
\hline No & Umur & Jumlah & $\%$ \\
\hline 1 & $\geq 16$ tahun & 16 & 76.2 \\
\hline 2 & $<16$ tahun & & 5 & 23.8 \\
\hline & & Jumlah & 21 & 100 \\
\hline
\end{tabular}

Dari Tabel diatas menunjukan bahwa peserta kegiatan pengabdian masyarakat tentang "Usaha Peningkatan Awareness, Pengetahuan, Sikap Siswa SMKN 2 Kota Jambi dalam Keselamatan Berkendara (Safety Riding) : Intervensi Haddon Matrix Framework, sebesar $76.2 \%$ berusia $\geq 16$ tahun .

Tabel 3. Distribusi Frekuensi Pengalaman Berkendara

\begin{tabular}{cccc}
\hline No & Umur & Jumlah & $\%$ \\
\hline 1 & $<1$ tahun & 6 & 28.6 \\
\hline 2 & 2 tahun & 2 & 8.5 \\
\hline 3 & 3 tahun & 3 & 28.6 \\
\hline 4 & 4 tahun & 7 & 33.3 \\
\hline & Jumlah & 21 & 100 \\
\hline
\end{tabular}

Dari Tabel diatas menunjukan bahwa peserta kegiatan pengabdian masyarakat tentang "Peningkatan Awareness, Pengetahuan, dan Sikap Siswa SMKN 2 Kota Jambi dalam Keselamatan Berkendara (Safety Riding): Intervensi Haddon Matrix Framework, sebesar 33,3\% memiliki pengalaman berkendara 4 tahun . 
BERNAS:

Jurnal Pengabdian Kepada Masyarakat

[Vol. 2 No 4, 2021, pp. 913-920]

Tabel 4. Distribusi Nilai Hasil Pre-test dan Post Test (Uji t)

\begin{tabular}{lllc}
\hline \multicolumn{1}{c}{ Variabel } & \multicolumn{1}{c}{ Nilai } & Mean & P-Value \\
\hline Pengetahuan & Pre-test & 7.85 & 0.005 \\
\hline Sikap & Post-test & 9.48 & \\
\hline & Pre-test & 27.71 & 0.001 \\
\hline
\end{tabular}

Dari tabel diatas menunjukan bahwa peserta kegiatan pengabdian masyarakat tentang "Usaha Peningkatan Awareness, Pengetahuan, dan Sikap Siswa SMKN 2 Kota Jambi dalam Keselamatan Berkendara (Safety Riding) : Intervensi Haddon Matrix Framework, menunjukkan bahwa untuk variabel pengetahuan terjadi peningkatan nilai rata-rata sebleum intervensi 7.85 menjadi 9.48 setelah intervensi dan secara statistik memiliki kemaknaan $P$ value : 0.005 . Sementara untuk variabel sikap terjadi peningkatan nilai rata-rata sebelum intervensi 27.71 menjadi 30.14 setelah dilakukan intervensi dan secara statistik memiliki kemaknaan $P$ value : 0.005 .

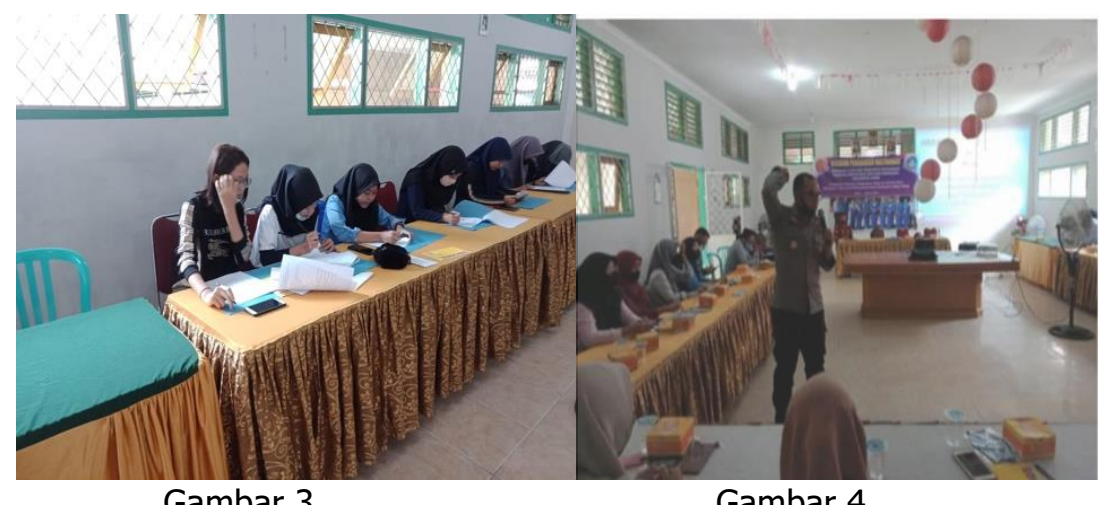

Gambar 3

Gambar 4

Keterangan Gambar:

Gambar 3: Peserta sedang menegrjakan pre dan post-test (dok. pribadi)

Gambar 4: Pemberian materi dari kepolisian mengenai safety riding (dok. pribadi)

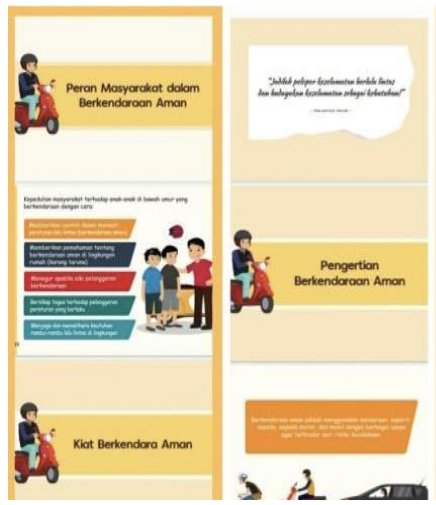

Gambar 5

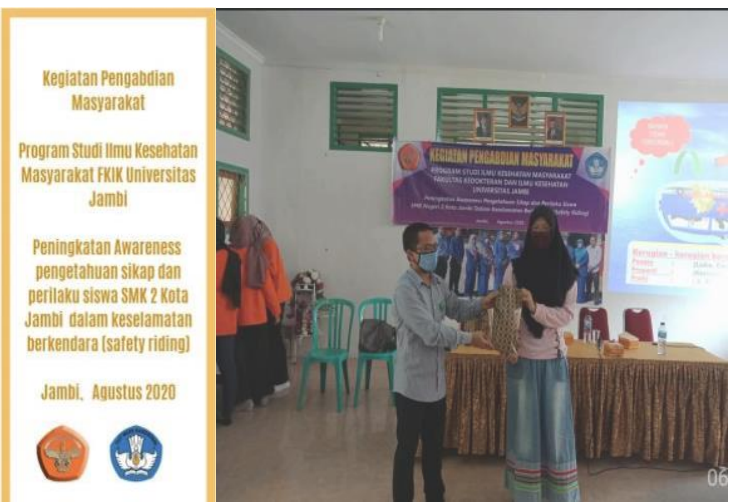

Gambar 6 


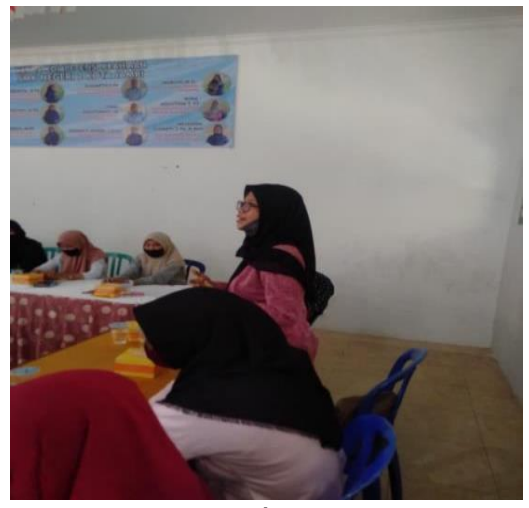

Gambar 7

Keterangan Gambar

Gambar 5: Media flieryang digunakan untuk edukasi dan penyuluhan ke siswa (dok.pribadi)

Gambar 6: Pemberian hadiah kepada peserta teraktif dan terbaik (dok.pribadi)

Gambar 7: Peserta sedang bertanya ke narasumber (dok.pribadi

Menurut Zao et.al 2019 mengatakan bahwa pelatihan secara signifikan dapat meningkatkan keselamatan berkendara, dan salah satu metode pelatihan yang berguna adalah harus menyadarkan pentingnya mematuhi peraturan lalu lintas. Untuk meningkatkan keselamatan berkendara, metode pelatihan yang efektif harus ditingkatkan dan diterapkan. Kedua penegakan peraturan lalu lintas dapat mencegah perilaku mengemudi yang buruk dan meningkatkan keselamatan berkendara, terutama bagi pengemudi laki-laki muda dengan sikap mengemudi yang buruk. Secara khusus, hukuman yang ketat bagi pelanggar, termasuk penangguhan atau pencabutan SIM, dan denda yang lebih tinggi, dapat meningkatkan keselamatan mengemudi dalam kondisi yang merugikan tersebut. Ketiga adalah melalui media iklan atau promosi. Iklan adalah metode yang sederhana dan menjanjikan untuk meningkatkan kesadaran pengemudi. Khususnya, iklan dapat menginformasikan pengemudi tentang pentingnya keselamatan berkendara.

Studi terkait perilaku berkendara juga perlu ditingkatkan, menurut (Yuen et. al 2014) hal ini dapat dijadikan dasar pembuat kebijakan untuk mengambil tindakan secara efektif untuk mengurangi jumlah kecelakaan dan karena itu menyelamatkan nyawa. Intervensi terhadap perubahan perilaku ini juga sangat penting karena dengan peningkatan perilaku yang safety akan berkorelasi positif dengan keselamatan berkendara (Muryatma 2017).

Pengembangan dan implementasi kerangka (framework) program untuk mengurangi kecelakaan akibat perilaku berisiko, salah satunya memerlukan dukungan dari pihak orang tua, selain itu orang tua dapat memberikan pengaruh positif yang cukup besar terhadap cara mengemudi anak remaja, membatasi kepemilikan kendaraan, dan dengan mencontohkan perilaku mengemudi yang aman (Shope 2006, Brookland et. al 2014), kepribadian yang terbentuk pada anak juga dipengaruhi oleh orang orang tua, hal ini menurun Chen 2009 ternayat faktor kepribadian (personality) juga bisa mempengaruhi periaku berisiko berkendara pada remaja. Oleh karena itu intervensi pada variabel ini juga perlu mendapatkan perhatian.

Perilaku pengendara menjadi penyebab sebagian besar kecelakaan sepeda motor di jalan raya (Yousif et.al 2019), gaya hidup dan perilaku berisiko seperti tidak memakai helm, menggunakan mobile phone saat berkendara (Patel et. a/2019, Truong et.a/2019, Stanojević et.al 2020). Kegiatan pengmas ini mencoba untuk melakukan intervensi pada faktor manusia dengan cara peningkatan awareness pengetahuan dan sikap dalam keselamatan berkendara sehingga diharapkan mampu sebagai usaha pencegahan dan pengurangan kecelakaan. Pendekatan yang diapakai merujuk pada konseptual framework dari Haddon Matrix sebagai kerangka paradigma 
dalam pencegahan kecelakaan dalam fase pre-crash kendaraan bermotor oleh human factor (Barnett et.a/ 2005, Bocage et.a/ 2020).

\section{Kesimpulan}

Berdasarkan hasil kegiatan pengabdian masyarakat yang telah dilakukan di SMKn2 Kota Jambi terkait Usaha Peningkatan Awareness, Pengetahuan, dan Sikap Siswa SMKN 2 Kota Jambi dalam Keselamatan Berkendara (Safety Riding) berlangsung cukup baik. Dari mulai pra perencanaan, perencanaan, maupun hasil evaluasi yang telah dilakukan. Terdapat perubahan secara statistik terkait parameter parameter yang diukur sebagai usaha ikut berkontribusi dalam pencegahan kejadian kecelakaan sepeda motor di kalangan remeja khususnya pelajar. Dari hasil pengukuran melalui kuesioner melalui mekanisme pre-test dan post-test, menunjukkan hasil bahwa untuk variabel pengetahuan terjadi peningkatan nilai rata-rata sebelum intervensi 7.85 menjadi 9.48 setelah intervensi dan scara statistik memiliki kemaknaan P-value sebesar 0.005 . Sementara untuk variabel sikap terjadi peningkatan nilai rata-rata sebleum intervensi 27.71 menjadi 30.14 setelah intervensi dan scara statistik memiliki kemaknaan $P$-value 0.005 .

Pelatihan ini semoga bisa menjadi kontribusi awal dalam penciptaan budaya keselamatan berkendara di kalangan siswa sekolah sehingga turut berkontribusi dalam pengurungan angka kecelakaan kendaraan bermotor. Intervensi berbagai macam variabel dengan pendekatan Haddon Matrix Framework terbukti cukup efektif terkait masalah safety riding dan pencegahan kecelakaan dan fatality yang ditimbulkan

\section{Daftar Pustaka}

Anaya, J. J., Ponz, A., García, F., \& Talavera, E. (2017). Motorcycle detection for ADAS through camera and V2V Communication, a comparative analysis of two modern technologies. Expert Systems with Applications, 77, 148-159.

Brookland, R., Begg, D., Langley, J., \& Ameratunga, S. (2014). Parental influence on adolescent compliance with graduated driver licensing conditions and crashes as a restricted licensed driver: New Zealand Drivers Study. Accident Analysis \& Prevention, 69, 30-39.

Barnett, D. J., Balicer, R. D., Blodgett, D., Fews, A. L., Parker, C. L., \& Links, J. M. (2005). The application of the Haddon matrix to public health readiness and response planning. Environmental health perspectives, 113(5), 561-566.

Bocage, C., Mashalla, Y., Motshome, P., Fane, O., Masilo-Nkhoma, L., Mathiba, O., ... \& Tam, V. (2020). Applying the Haddon matrix conceptual model to guide motor vehicle crash injury research and prevention in Botswana. African Journal of Emergency Medicine.

Chen, C. F. (2009). Personality, safety attitudes and risky driving behaviors-Evidence from young Taiwanese motorcyclists. Accident Analysis \& Prevention, 41(5), 963-968.

Depkes, P. (2010). Kesehatan remaja problem dan solusinya. Jakarta: Salemba Medika.

https://www.cdc.gov/motorvehiclesafety/mc/index.html

Muryatma, N. M. (2017). Hubungan antara Faktor Keselamatan Berkendara dengan Perilaku Keselamatan Berkendara. Jurnal Promkes: The Indonesian Journal of Health Promotion and Health Education, 5(2), 155-166.

Notoatmodjo, S. (2005). Promosi Kesehatan: Teori dan Aplikasi. Jakarta: Rineka Cipta, 52-54

Nyagwui, A. E., Fredinah, N., Che, L. B., \& Yulia, B. (2016). Motorcycle injury among secondary school students in the Tiko municipality, Cameroon. Pan African medical journal, 24(1).

O'Neill, B., \& Mohan, D. (2002). Reducing motor vehicle crash deaths and injuries in newly motorising countries. Bmj, 324(7346), 1142-1145. 
Patel, P. B., Staley, C. A., Runner, R., Mehta, S., \& Schenker, M. L. (2019). Unhelmeted motorcycle riders have increased injury burden: a need to revisit universal helmet laws. Journal of surgical research, 242, 177-182.

Petridou, E., \& Moustaki, M. (2000). Human factors in the causation of road traffic crashes. European journal of epidemiology, 16(9), 819-826.

Shope, J. T. (2006). Influences on youthful driving behavior and their potential for guiding interventions to reduce crashes. Injury Prevention, 12(suppl 1), i9-i14.

Stankovic, D., Stanojević, P., Jovanović, D., \& Lipovac, K. (2020). Impact of riders' lifestyle on their risky behavior and road traffic accident risk. Journal of Transportation Safety \& Security, 12(3), 400-418.

Truong, L. T., Nguyen, H. T., \& De Gruyter, C. (2019). Mobile phone use while riding a motorcycle and crashes among university students. Traffic injury prevention, 20(2), 204-210.

Tedjo, B. DAFTAR PUSTAKA. Ahmadi, D Psikologi Pendidikan. Jakarta: PT. Rineka Cipta.

World Health Organization. (2018). Global status report on road safety 2018: Summary (No. WHO/NMH/NVI/18.20). World Health Organization.

Yousif, M. T., Sadullah, A. F. M., \& Kassim, K. A. A. (2019). A review of behavioural issues contribution to motorcycle safety. IATSS Research.

Yuen, C. W., Karim, M. R., \& Saifizul, A. (2014). Investigation on motorcyclist riding behaviour at curve entry using instrumented motorcycle. The Scientific World Journal, 2014.

Zhao, X., Xu, W., Ma, J., Li, H., \& Chen, Y. (2019). An analysis of the relationship between driver characteristics and driving safety using structural equation models. Transportation research part F: traffic psychology and behaviour, 62, 529-545. 